\title{
THE VALUE OF DIFFERENT THERAPEUTIC AGENTS IN THE TREATMENT OF RICKETS
}

\author{
BY
}

OLIVE MACRAE, M.B., Ch.B.

(From the Dept. of Pædiatrics, Glasgow University, and Biochemical Dept., Royal Hospital for Sick Children, Glasgow.)

Within recent years great advances have been made in our knowledge of the exciting factor in the production of rickets, and as a consequence of this many new methods of treating the disease have been introduced. The widespread incidence of rickets makes an investigation of the value of the different forms of treatment a matter of great practical importance. The object of the present work is to demonstrate the relative value of some of these different methods by a comparative study of their influence on the radiological picture, the calcium and phosphorus contents of the blood, and the retentions of calcium and phosphorus.

Although the absence of sunlight as a cause of rickets was suggested by Huntly ${ }^{1}$ as long ago as 1889 it was not until 1919 that, in consequence of the work of Huldschinsky ${ }^{2}$ definite evidence was brought forward. This author was successful in effecting cure by exposure of the body to ultra-violet rays emanating from a mercury-vapour quartz-lamp. Since then many workers have published their results with this therapeutic measure, and it is now generally accepted that the length of time which elapses before healing becomes apparent in radiograms is from two to five weeks. Chick ${ }^{3}$ in Vienna noted healing in from two to four weeks after commencement of irradiation and Carter Braine and Osman ${ }^{4}$ report cases in which healing appeared after two to five weeks of ultra-violet ray therapy. In a series of five cases Kramer, Casparis and Howland $^{5}$ reported the effect of irradiation on the X-ray picture and the blood serum findings. They noted that healing became evident within four weeks from commencement of treatment and that the inorganic phosphorus content of the blood rose from 3 to $6 \mathrm{mgrm}$. per $100 \mathrm{c.cm}$. of serum in 6 to 11 weeks.

Fewer cases have been reported in which the retention of lime has been studied. In 1921 Meyer $^{6}$ contrasted the effect of cod-liver oil and that of ultraviolet light on craniotabes, and concluded that ultra-violet light was equal, or even superior, to cod-liver oil. In two cases he found a considerable increase in the retention of lime during ultra-violet light treatment. Orr, Holt, Wilkins and $\mathrm{Boone}^{7}$ have also reported an increase in the retentions of $\mathrm{CaO}$ and $\mathrm{P}_{2} \mathrm{O}_{5}$ in cases of infantile rickets treated with ultra-violet light.

Although there have been many reports on the effect of administration of various preparations of irradiated ergosterol on the course of rickets, so far no observations have been published on the effect of this substance in therapeutic doses on the retention of $\mathrm{CaO}$ and $\mathrm{P}_{2} \mathrm{O}_{5}$. Karelitz ${ }^{8}$, giving vigantol in doses 
equivalent to $3 \cdot 3 \mathrm{mgrm}$. of irradiated ergosterol daily, found healing in the radiographic picture as early as 7 days. The average time of the first appearance of healing however was 21 days from commencement of treatment, and the inorganic phosphorus content of the serum rose to normal in 14 to 21 days. Gyorgy ${ }^{9}$, Vollmer ${ }^{10}$ and other German workers also using vigantol have reported similar results. In a series of 5 cases treated with radiostol Aidin ${ }^{11}$ found the earliest radiological evidence of healing in from 3 to 8 weeks.

Present investigations. - In the present investigation different methods of treatment were studied in $\mathbf{1 4}$ cases of active rickets. The course of the disease was followed in all cases in weekly radiograms for at least three weeks before the commencement of treatment, and with two exceptions, the patients were in hospital during the entire period of observation. The effect of treatment was noted (1) on the calcification of the bones as seen on radiological examination, (2) on the calcium and inorganic phosphorus contents of the blood serum, and (3) on the retentions of $\mathrm{CaO}$ and $\mathrm{P}_{2} \mathrm{O}_{5}$.

Mетнор. The method used for the determination of the calcium content of the serum was that of Kramer and Tisdall ${ }^{12}$, and Tisdall's ${ }^{13}$ method was used for the determination of the inorganic phosphorus content of the serum.

In all cases in which it was possible a metabolic study was made before treatment and during the second week of treatment. Each metabolic study extended over a period of seven days, the diet being constant for at least three days prior to the actual metabolic investigation. The usual gravimetric methods were used for the determination of $\mathrm{CaO}$ in urine and of $\mathrm{P}_{2} \mathrm{O}_{5}$ in fæces, urine, and milk. Lime in the fæces and milk was precipitated as oxalate and titrated with deci-normal permanganate.

The cases are divided into four groups according to the method of treatment employed.

Group 1 consists of five cases who received direct irradiation of the skin. Of these, three were examples of ordinary infantile rickets, and the other two were older children, a boy aged $9 \frac{1}{2}$ years and a girl aged 12 years. The boy (Case 4) was admitted to hospital on account of difficulty in walking: he had first started to walk at the age of 3 years but always tired quickly and tended to fall : from the age of 6 years till the date of admission the condition became worse : on admission he appeared small $(12 \mathrm{~cm}$. below average height) but well nourished with epiphyseal enlargement and marked genu valgum. In the case of the girl it was noted that the knee had been 'turned in ' for one year, during the last month of which, she dragged the right leg in walking. She was a fair-sized girl with a slight degree of genu valgum. In both these cases radiological examination showed a fairly marked degree of active rachitic change.

Treatment was begun by exposing the back for 2 minutes to radiations from a mercury-vapour quartz-lamp at a distance of $4 \mathrm{ft}$. The exposures were increased daily according to the tolerance of the skin.

Group 2 includes four examples of infantile rickets treated with radiostol. Three of the children received $4 \mathrm{~min}$. of a solution of radiostol in oil three times daily; and one, who was an out-pationt (Case 9) was given two radiostol pellets daily.

In Group 3 are three cases (one of which, Case 10, was an out-patient) treated with two pellets of vigantol daily ( 1 pellet $=4 \mathrm{mgrm}$. irradiated ergosterol), 
Group 4 includes two cases treated with one drachm of cod-liver oil three times daily.

The results are summarized in Table 1.

Radiological findings. - In the group of cases treated with irradiation the time between the commencement of treatment and the first appearance of healing noted on X-ray examination varied from 12 days to 4 weeks. Taking

TABLE 1.

EFFECT OF DIFFERENT FORMS OF TREATMENT ON RADIOGRAMS, SEROLOGICAL FINDINGS AND MINERAL RETENTION.

\begin{tabular}{|c|c|c|c|c|c|c|c|c|c|c|c|c|}
\hline \multirow{3}{*}{$\begin{array}{l}\text { Case } \\
\text { No. }\end{array}$} & \multirow{3}{*}{$\begin{array}{l}\text { Age } \\
\text { in } \\
\text { years }\end{array}$} & \multirow{3}{*}{ Treatment } & \multicolumn{2}{|c|}{ Radiograms. } & \multicolumn{4}{|c|}{ Blood chemistry. } & \multicolumn{4}{|c|}{ Daily retention per krgm. } \\
\hline & & & \multirow{2}{*}{$\begin{array}{c}\text { First } \\
\text { appearance } \\
\text { of healing }\end{array}$} & \multirow{2}{*}{$\begin{array}{l}\text { Subse- } \\
\text { quent } \\
\text { healing }\end{array}$} & \multicolumn{2}{|c|}{$\begin{array}{c}\text { Before } \\
\text { treatment. }\end{array}$} & \multicolumn{2}{|c|}{$\begin{array}{l}\text { End of } 2 \text { ndweek } \\
\text { of treatment. }\end{array}$} & \multicolumn{2}{|c|}{$\begin{array}{c}\text { Before } \\
\text { treatment. }\end{array}$} & \multicolumn{2}{|c|}{$\begin{array}{c}\text { Fnd of } 2 \text { nd week } \\
\text { of treatment. }\end{array}$} \\
\hline & & & & & $\begin{array}{c}\text { Serum } \\
\mathrm{Ca} \\
\text { mgrm. } \\
\%\end{array}$ & $\begin{array}{c}\text { Serum } \\
P \\
\text { mgrm. } \\
\%\end{array}$ & $\begin{array}{c}\text { Serum } \\
\mathrm{Ca} \\
\text { mgrm. } \\
\%\end{array}$ & $\begin{array}{c}\text { Serum } \\
\mathrm{P} \\
\text { mgrm. } \\
\%\end{array}$ & $\begin{array}{l}\mathrm{CaO} \\
\text { grm. }\end{array}$ & $\begin{array}{l}\mathrm{P}_{2} \mathrm{O}_{5} \\
\text { grm. }\end{array}$ & $\begin{array}{l}\mathrm{CaO} \\
\text { grm. }\end{array}$ & $\begin{array}{l}\mathrm{P}_{2} \mathrm{O}_{5} \\
\text { grm. }\end{array}$ \\
\hline 1 & $1 \frac{8}{1 \frac{2}{2}}$ & Irradiation & 3 weeks & rapid & $8 \cdot 13$ & $2 \cdot 5$ & $10 \cdot 47$ & $4 \cdot 3$ & - & 一 & 一 & 一 \\
\hline 2 & $2 \frac{b}{12}$ & , & 12 days & & $9 \cdot 56$ & $2 \cdot 8$ & $\overline{1000}$ & $5 \cdot 8$ & & & & \\
\hline 3 & $2 \frac{7}{12}$ & , & $\begin{array}{l}2 \text { weeks } \\
2 \text { weeks }\end{array}$ & & $\begin{array}{c}7 \cdot 29 \\
-\end{array}$ & $\begin{array}{l}4 \cdot 3 \\
4 \cdot 1\end{array}$ & $\begin{array}{c}10 \cdot 09 \\
-\end{array}$ & $\begin{array}{l}4 \cdot 3 \\
6 \cdot 4\end{array}$ & $\begin{array}{r}+.039 \\
-.003\end{array}$ & $\begin{array}{l}+.045 \\
+.004\end{array}$ & $\begin{array}{l}+\cdot 255 \\
+\cdot 10\end{array}$ & $\begin{array}{l}+\cdot 220 \\
+.08\end{array}$ \\
\hline $\begin{array}{l}\mathbf{4} \\
5\end{array}$ & 12 & ", & 4 weeks & slow & $11 \cdot 2$ & $\begin{array}{l}\mathbf{1}+1 \\
3 \cdot 0\end{array}$ & $11 \cdot 08$ & $5 \cdot 2$ & +.03 & $\begin{array}{l}+\cdot 004 \\
+\cdot 02\end{array}$ & $\begin{array}{l}+.10 \\
+.08\end{array}$ & $\begin{array}{l}+\cdot 08 \\
+\cdot 08\end{array}$ \\
\hline 6 & $1_{1}^{\frac{2}{2}}$ & Radiostol & $4 \frac{1}{2}$ weeks & slow & 一 & $3 \cdot 4$ & 一 & $4 \cdot 0$ & 一 & 一 & 一 & - \\
\hline 7 & $\frac{6}{12}$ & , & 2 weeks & rapid & $8 \cdot 46$ & $4 \cdot 0$ & $9 \cdot 9$ & $5 \cdot 1$ & $+\cdot 042$ & $+\cdot 043$ & $+\cdot 104$ & $+\cdot 080$ \\
\hline 8 & $3 \frac{1}{2}$ & , & 3 weeks & slow & $10 \cdot 04$ & $3 \cdot 0$ & 一 & $4 \cdot 4$ & - & - & - & - \\
\hline 9 & $3 \frac{1}{2}$ & , & $5 \frac{1}{2}$ weeks & slow & $8 \cdot 6$ & $3 \cdot 1$ & $9 \cdot 2$ & $\begin{array}{c}3 \cdot 7 \\
\left(7 \frac{1}{2} \text { wks. }\right)\end{array}$ & - & 一 & - & - \\
\hline 10 & $2 \frac{1}{2}$ & Vigantol & 2 weeks & rapid & $9 \cdot 2$ & $2 \cdot 0$ & $9 \cdot 4$ & $4 \cdot 1$ & - & 一 & - & - \\
\hline 11 & $1 \frac{1}{1} \frac{1}{2}$ & ", & 1 week & rapid & $5 \cdot 1$ & $7 \cdot 1$ & $8 \cdot 1$ & 4.4 & - & - & - & - \\
\hline 12 & $1 \frac{1}{2}$ & ", & 1 week & slow & $4 \cdot 0$ & $4 \cdot 8$ & $10 \cdot 2$ & $\begin{array}{c}9 \cdot 2 \\
(3 \text { wks.) }\end{array}$ & $+\cdot 027$ & $+\cdot 037$ & $+\cdot 124$ & +.097 \\
\hline 13 & 2 & Cod-liver oil & 17 days & rapid & $10 \cdot 04$ & $3 \cdot 0$ & - & $4 \cdot 0$ & - & - & - & - \\
\hline 14 & 2 & ", & 18 days & rapid & $8 \cdot 5$ & $2 \cdot 1$ & $8 \cdot 84$ & $3 \cdot 33$ & $+\cdot 039$ & $+\cdot 048$ & $+\cdot 153$ & $+\cdot 156$ \\
\hline
\end{tabular}

the cases of infantile rickets only, it varied from 12 days to 3 weeks. With the use of cod-liver oil healing became evident in $2 \frac{1}{2}$ weeks, and with vigantol in 1 to 2 weeks. In the cases treated with radiostol this period was somewhat longer, varying from 2 weeks to $5 \frac{1}{2}$ weeks, the average being $3 \frac{3}{4}$ weeks. The subsquent rate of healing as judged from radiological evidence. was, on the whole, slower in those cases treated with radiostol than in the patients who received the other forms of treatment (see Table 1).

Changes in serum calcium and phosphorus.-Group 1. The behaviour of the serum calcium and phosphorus in the group of cases treated with ultraviolet light is shown in Charts I and II. Two of these cases (No. 1 and 3) were complicated by latent tetany, and in both the serum calcium rapidly rose to normal after 1 to 3 weeks of treatment. In four of the cases the initial level of the serum phosphorus was low, varying from $2 \cdot 1$ to $3.9 \mathrm{mgrm}$., and rose to a maximum of between 6.5 and 7 mgrm. in $2 \frac{1}{2}$ to 6 weeks. Chart II illustrates the continued improvement in Case 3 after the cessation of treatment. 
CHART I.

Treatment with Ulitra-viofeet light.

Case 1.

Case 2. (rickets and latent tetany) _......

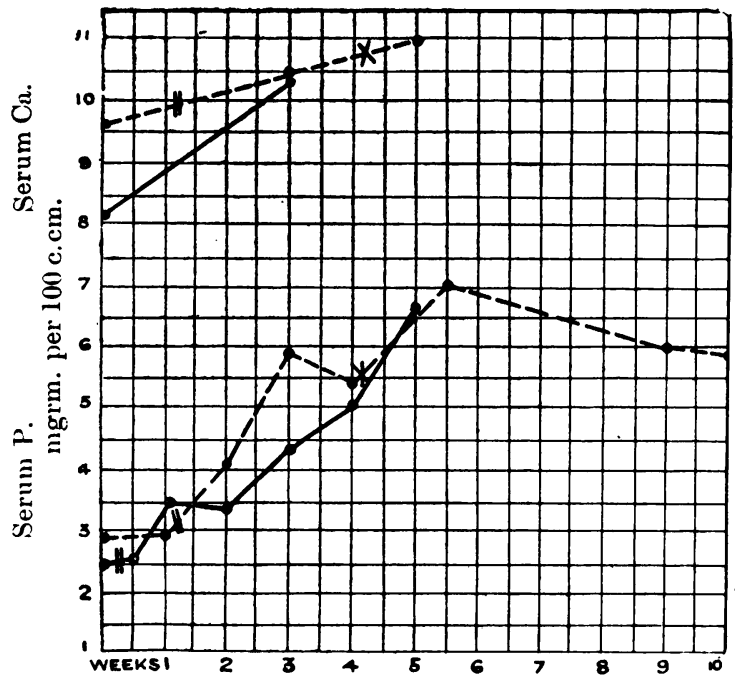

Case 4.

Case 5.

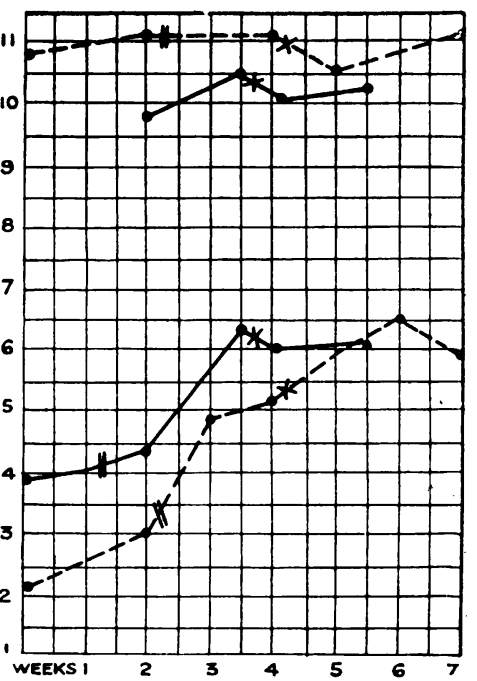

$x$ indicates cessation of treatment.

CHAR'T II.

Theathext With VITKA-YIOLET I.IGHT.

Case 3. (cickets and latent tetany) showing continued improvement after cessation of treatment.

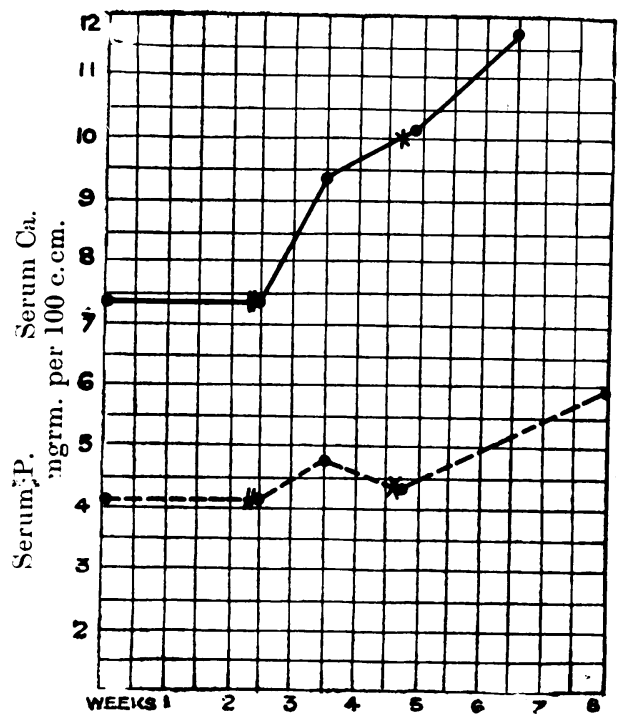

it indicates onset of treatment.

$x$ indicates cessation of treatment. 
Group 2. In the cases treated with radiostol the blood changes were not so marked (Chart III). In Case 6, which had an initial normal serum calcium of $9.49 \mathrm{mgrm}$. per $100 \mathrm{c.cm}$. and a serum phosphorus of $3.4 \mathrm{mgrm}$., the rise in the serum phosphorus to a maximum of $5.8 \mathrm{mgrm}$. occurred in $6 \frac{1}{2}$ weeks. In Case 8, which also had a normal serum calcium, the phosphorus had not risen above $4.7 \mathrm{mgrm}$. at the end of 6 weeks of treatment. Administration of radiostol was then omitted and cod-liver oil in one-drachm doses given three times daily. The serum phosphorus rose rapidly reaching a height of $8 \mathrm{mgrm}$. in two weeks, thereafter showing a gradual fall. In Case 9, which was treated as an out-patient, it took $7 \frac{1}{2}$ weeks for the serum phosphorus to rise from $3 \cdot 1$ to $3.7 \mathrm{mgrm}$., and the serum calcium to rise from 8.6 to $9.2 \mathrm{mgrm}$. (Table 1 ).

CHAR'T III.

Treatalest With kabiostol.

Case 8.

Case 7. (rickets and latent tetany) -

Case 6. -......-

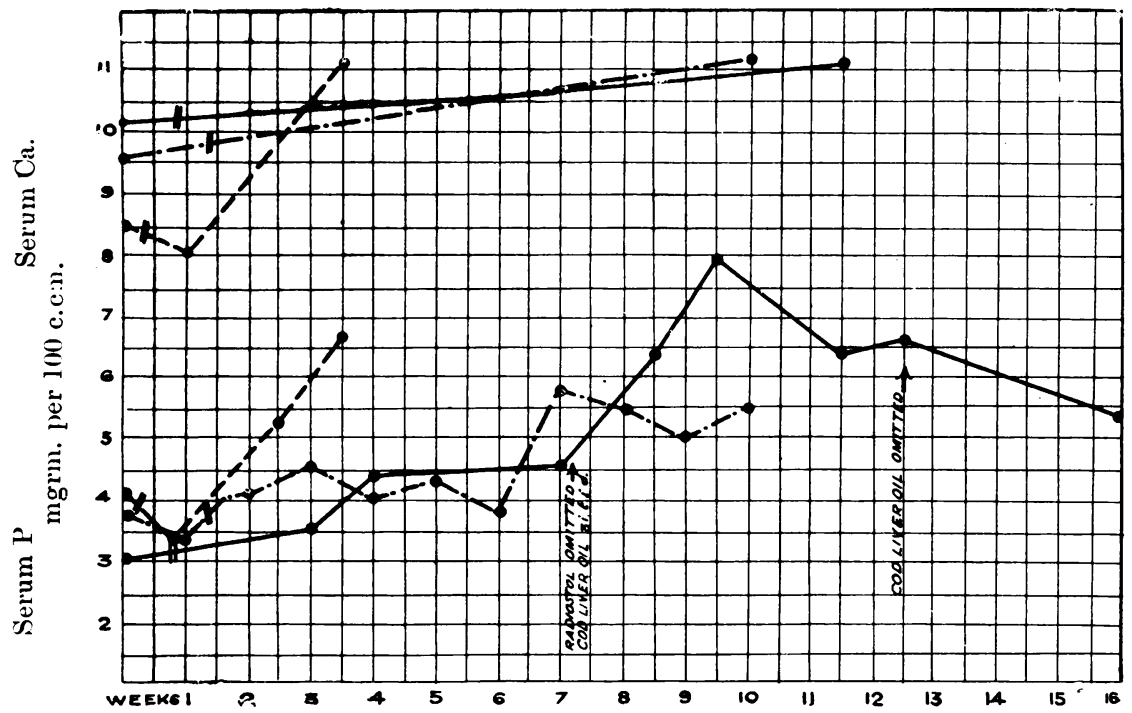

$\|$ indicates onset of treatment

In Case 7, which had had an initial serum calcium of $8.5 \mathrm{mgrm}$. and serum phosphorus of $4.0 \mathrm{mgrm}$. the values of both rose rapidly to $11 \cdot 1$ and $6 \cdot 1 \mathrm{mgrm}$. respectively after treatment for three weeks.

Group 3. In the two in-patients (Cases 11 and 12) who were treated with vigantol, Chvostek's sign was present and both had laryngismus. The serum calcium was very low, being $5 \cdot 1 \mathrm{mgrm}$. in Case 11 , and $4 \cdot 0 \mathrm{mgrm}$. in Case 12. After three weeks treatment the value for the serum calcium rose in the former to $9 \cdot 1$, and in the latter to $10 \cdot 2 \mathrm{mgrm}$. (Chart IV). In Case 10, which was treated as an out-patient, the initial serum calcium was normal. The serum phosphorus which was 2.0 before treatment rose to $4 \cdot 1 \mathrm{mgrm}$. in 2 weeks (Table 1).

Group 4. Of the two children treated with cod-liver oil one (Case 14) had latent tetany, the serum calcium being $8.5 \mathrm{mgrm}$. During the first four 
CHART IV.

Treatuent with vightot.

Calcium content of serum.

Cases 11. (rickets and tetany).

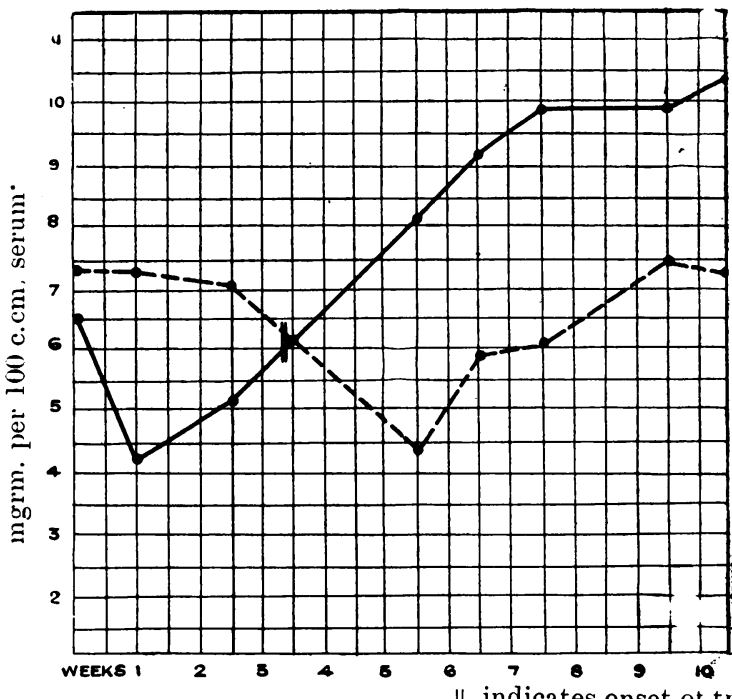

-- Inorganic phospherous content of serum. Case 12. (rickets and tetany).

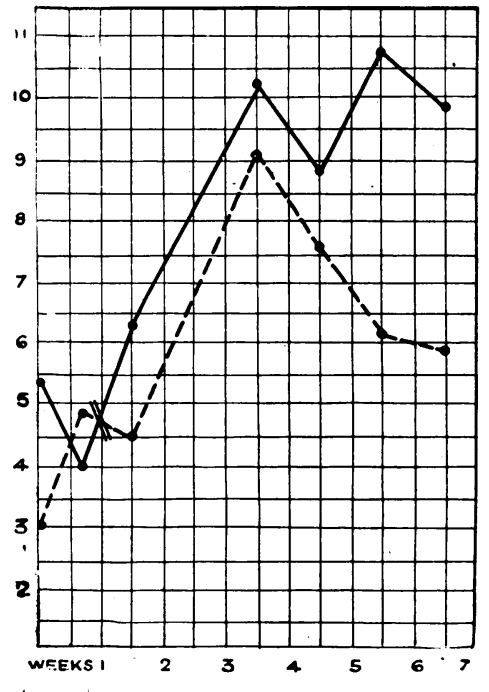

weeks of treatment this figure varied between 8.8 and $9.2 \mathrm{mgrm}$., and then rose to $10 \cdot 8$ at the end of $7 \frac{1}{2}$ weeks while the value for the serum phosphorus showed a gradual increase from $2 \cdot 1$ to $5.4 \mathrm{mgrm}$. In the other patient (Case 13) whose serum calcium was normal, the serum phosphorus showed a more rapid increase, reaching a maximum of $7 \mathrm{mgrm}$. in $6 \frac{1}{2}$ weeks (Chart V).

CHAR'T $V$.

Trkatuent With (OD)-I.IVER OIL.

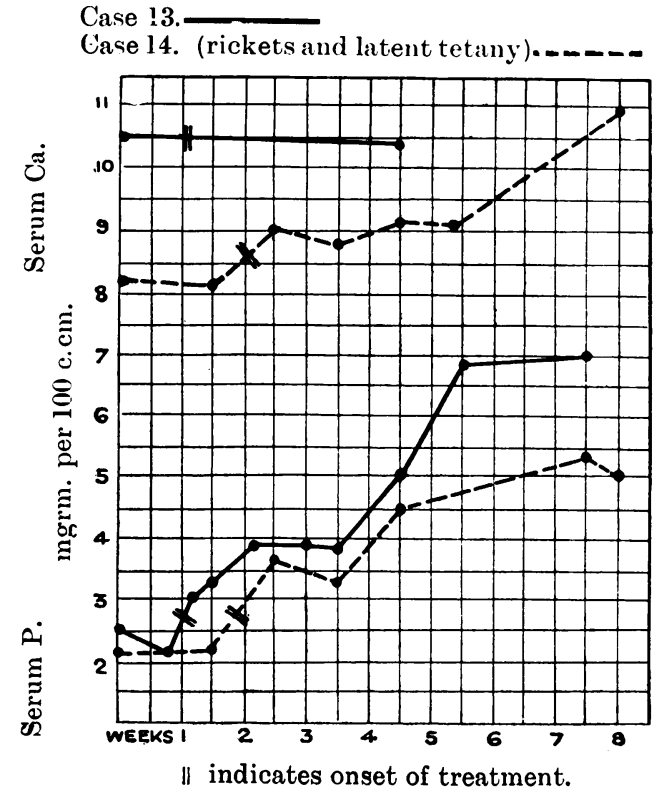


From these results it will be seen that the blood changes produced by the different methods of treatment were very similar, although with the use of radiostol the increase in serum phosphorus was somewhat less marked.

Metabolism studies.-A study of the calcium and phosphorus metabolism was obtained in one case of infantile rickets from each of the four groups. The results are shown in Table 2 . In all the cases before treatment the classical picture of active rickets was found, namely, a high fæcal output of $\mathrm{CaO}$ and $\mathrm{P}_{2} \mathrm{O}_{5}$. During treatment a very high retention of $\mathrm{CaO}$ and $\mathrm{P}_{2} \mathrm{O}_{5}$ was brought

TABLE 2.

Metabolism of CaO and $\mathrm{P}_{2} \mathrm{O}_{5}$ in four cases of Infantile rickets BEFORE AND DLRING SECOND WEEK OF TREATMRNT

\begin{tabular}{|c|c|c|c|c|c|c|c|c|c|c|c|c|c|c|c|}
\hline \multirow{2}{*}{$\begin{array}{l}\text { Case } \\
\text { No. }\end{array}$} & \multirow{2}{*}{$\begin{array}{l}\text { Age } \\
\text { in } \\
\text { years }\end{array}$} & \multirow{2}{*}{ Period } & \multicolumn{2}{|c|}{ Total intake } & \multicolumn{2}{|c|}{ Total output } & \multicolumn{2}{|c|}{ Fæcal output } & \multicolumn{2}{|c|}{$\begin{array}{l}\text { Urinary } \\
\text { output }\end{array}$} & \multirow{2}{*}{ 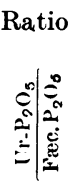 } & \multicolumn{2}{|c|}{$\begin{array}{c}\text { Total } \\
\text { retention }\end{array}$} & \multicolumn{2}{|c|}{$\begin{array}{l}\text { Daily reten- } \\
\text { tion per kgrm. }\end{array}$} \\
\hline & & & $\begin{array}{l}\mathrm{CaO} \\
\text { grm. }\end{array}$ & $\begin{array}{l}\mathrm{P}_{2} \mathrm{O}_{5} \\
\text { grm. }\end{array}$ & $\begin{array}{l}\mathrm{CaO} \\
\text { grm. }\end{array}$ & $\begin{array}{l}\mathrm{P}_{2} \mathrm{O}_{5} \\
\text { grm. }\end{array}$ & $\begin{array}{l}\mathrm{CaO} \\
\text { grm. }\end{array}$ & $\begin{array}{l}\mathrm{P}_{2} \mathrm{O}_{5} \\
\text { grm. }\end{array}$ & $\begin{array}{l}\mathrm{CaO} \\
\text { grm. }\end{array}$ & $\begin{array}{l}\mathrm{P}_{2} \mathrm{O}_{5} \\
\text { grm. }\end{array}$ & & $\begin{array}{l}\mathrm{CaO} \\
\text { grm. }\end{array}$ & $\begin{array}{l}\mathrm{P}_{2} \mathrm{O}_{5} \\
\text { grm. }\end{array}$ & $\begin{array}{l}\mathrm{CaO} \\
\text { grm. }\end{array}$ & $\begin{array}{l}\mathrm{P}_{2} \mathrm{O}_{5} \\
\mathrm{grm} .\end{array}$ \\
\hline 3 & $2 \frac{7}{1}=$ & $\begin{array}{l}\text { Before } \\
\text { treatment } \\
\text { During } \\
\text { irradiation } \quad . .\end{array}$ & $\begin{array}{l}16 \cdot 632 \\
16 \cdot 632\end{array}$ & \begin{tabular}{|}
$21 \cdot 672$ \\
$21 \cdot 672$
\end{tabular} & $14 \cdot 336$ & 18.993 & $14 \cdot 286$ & 13.823 & .050 & $7 \cdot 595$ & $\frac{1}{2.7}$ & \begin{tabular}{r|}
$2 \cdot 296$ \\
$14 \cdot 428$
\end{tabular} & $\begin{array}{c}2 \cdot 679 \\
12 \cdot 471\end{array}$ & $\begin{array}{l}.039 \\
.255\end{array}$ & $\begin{array}{l}.045 \\
.220\end{array}$ \\
\hline 7 & $\frac{6}{15}$ & $\begin{array}{l}\text { Before } \\
\text { treatment } \\
\text { During admin- } \\
\text { istration of } \\
\text { Radiostol .. }\end{array}$ & $11 \cdot 157$ & $15 \cdot 592$ & 5.926 & $13 \cdot 473$ & $9 \cdot 047$ & $2 \cdot 137$ & $\cdot 155$ & $5 \cdot 18$ & $\begin{array}{c}1 \\
1.6\end{array}$ & $2 \cdot 075$ & $2 \cdot 119$ & .042 & .043 \\
\hline 12 & $1 \frac{6}{r^{2}}$ & $\begin{array}{l}\text { Before } \\
\text { treatment .. } \\
\text { During admin- } \\
\text { istration of } \\
\text { Vigantol ... }\end{array}$ & $12 \cdot 60$ & $17 \cdot 64$ & $10 \cdot 869$ & $15 \cdot 331$ & $10 \cdot 693$ & $10 \cdot 613$ & $\cdot 220$ & $4 \cdot 718$ & $\frac{1}{2.2}$ & $7 \cdot 780$ & $2 \cdot 309$ & $\cdot 124$ & .037 \\
\hline 14 & $2_{1}^{2}$ & $\begin{array}{l}\text { Before } \\
\text { treatment .. } \\
\text { During admin- } \\
\text { istration of } \\
\text { Cod-Liver oil }\end{array}$ & $11 \cdot 76$ & $16 \cdot 17$ & $4 \cdot 356$ & $13 \cdot 849$ & $4 \cdot 272$ & $10 \cdot 721$ & .095 & $3 \cdot 128$ & $\frac{1}{3 !}$ & 1.912 & $2 \cdot 321$ & $\cdot 153$ & $\cdot 156$ \\
\hline
\end{tabular}

about by a marked diminution in the fæcal output of these substances. The greatest increase in retention was obtained with direct irradiation, the retention of lime being increased during this treatment roughly six times. With the use of vigantol and cod-liver oil the retention of $\mathrm{CaO}$ was increased approximately four times, and with radiostol $2 \frac{1}{2}$ times. It is interesting to note that the urinary output of $\mathrm{P}_{2} \mathrm{O}_{5}$ was increased during the healing phase in every case, and the excretion of $\mathrm{CaO}$ by the kidneys was increased during healing in every instance except Case 14, in which practically no change was noted. 
Metabolism studies were also obtained in the two older children belonging to Group 1 (Table 3). Owing, however, to the slight differences in the mode of excretion and retention at this later age these figures cannot be compared directly with the figures for the metabolic studies in the younger patients. In both patients before treatment there was a high fæcal output of $\mathrm{CaO}$ and

TABLE 3.

Metabolism of CaO and $\mathrm{P}_{2} \mathrm{O}_{5}$ in two older children before and during Second week of treatment.

\begin{tabular}{|c|c|c|c|c|c|c|c|c|c|c|c|c|c|c|c|}
\hline $\begin{array}{l}\text { Case } \\
\text { No. }\end{array}$ & $\begin{array}{l}\text { Age } \\
\text { in } \\
\text { years }\end{array}$ & , Period & \multicolumn{2}{|c|}{ Total intake } & \multicolumn{2}{|c|}{ Total output } & \multicolumn{2}{|c|}{ Fæcal output } & \multicolumn{2}{|c|}{$\begin{array}{l}\text { Urinary } \\
\text { output }\end{array}$} & $\begin{array}{l}\text { Ratio } \\
\frac{\text { Ur.P }}{\text { Fac.P }}\end{array}$ & \multicolumn{2}{|c|}{$\begin{array}{c}\text { Total } \\
\text { retention }\end{array}$} & \multicolumn{2}{|c|}{$\begin{array}{l}\text { Daily reten- } \\
\text { tion per kgrm. }\end{array}$} \\
\hline 4 & 9 & $\begin{array}{l}\text { Before } \\
\text { treatment } \\
\text { During } \\
\text { irradiation }\end{array}$ & $\begin{array}{l}16 \cdot 80 \\
16 \cdot 80\end{array}$ & $\begin{array}{l}23 \cdot 10 \\
23 \cdot 10\end{array}$ & $\begin{array}{r}17 \cdot 362 \\
2 \cdot 776\end{array}$ & $22 \cdot 507$ & $\begin{array}{r}17 \cdot 293 \\
2 \cdot 673\end{array}$ & \begin{tabular}{r|}
$12 \cdot 006$ \\
$1 \cdot 803$
\end{tabular} & .069 & $\begin{array}{r}10 \cdot 501 \\
9 \cdot 995\end{array}$ & $\begin{array}{l}\frac{1}{1.14} \\
\frac{5.5}{1}\end{array}$ & -0.55 & $\begin{array}{r}+0 \cdot 593 \\
11 \cdot 302\end{array}$ & $\begin{array}{l}-.003 \\
+.099\end{array}$ & $\begin{array}{l}+\cdot 002 \\
+\cdot 080\end{array}$ \\
\hline 5 & $12 \frac{1}{2}$ & $\begin{array}{l}\text { Before } \\
\text { treatment } \\
\text { During } \\
\text { irradiation }\end{array}$ & $\begin{array}{l}20 \cdot 16 \\
20 \cdot 16\end{array}$ & $\begin{array}{l}27 \cdot 72 \\
27 \cdot 72\end{array}$ & $\begin{array}{r}14 \cdot 719 \\
6 \cdot 073\end{array}$ & $13 \cdot 801$ & $\begin{array}{r}14 \cdot 431 \\
4 \cdot 753\end{array}$ & $4 \cdot 332$ & $1 \cdot 32$ & $\begin{array}{l}9 \cdot 603 \\
9 \cdot 469\end{array}$ & $\begin{array}{l}\frac{1}{1.4} \\
\frac{2.2}{1}\end{array}$ & $14 \cdot 087$ & $13 \cdot 919$ & $\begin{array}{l}+.029 \\
+.079\end{array} \mid$ & $\begin{array}{l}+.022 \\
+\cdot 078\end{array}$ \\
\hline
\end{tabular}

TABLE 4.

ANALYSES OF Feces Before aNd DURING TREATMENT OF INFANTILE RICKETS.

\begin{tabular}{|c|c|c|c|c|c|c|c|c|c|}
\hline & & \multicolumn{2}{|c|}{$\begin{array}{c}\text { Case 3. } \\
\text { (Irradiation) }\end{array}$} & \multicolumn{2}{|c|}{$\begin{array}{c}\text { Case } 7 . \\
\text { (Radiostol) }\end{array}$} & \multicolumn{2}{|c|}{$\begin{array}{l}\text { Case } 12 . \\
\text { (Vigantol) }\end{array}$} & \multicolumn{2}{|c|}{$\begin{array}{c}\text { Case } 14 . \\
\text { (Cod-liver oil) }\end{array}$} \\
\hline & & 1st Per. & 2nd Per. & lst Per. & 2nd Per. & 1st Per. & 2nd Per. & Ist Per. & 2nd Per. \\
\hline Fæcal wt. (grm.) & . & $66 \cdot 14$ & $32 \cdot 13$ & $125 \cdot 65$ & $71 \cdot 25$ & $80 \cdot 4$ & $82 \cdot 15$ & $69 \cdot 17$ & $48 \cdot 0$ \\
\hline$\%$ Ash $\ldots \quad \ldots$ & .. & $49 \cdot 0$ & $18 \cdot 8$ & $24 \cdot 0$ & $17 \cdot 5$ & $33 \cdot 28$ & $15 \cdot 15$ & $36 \cdot 0$ & $21 \cdot 8$ \\
\hline Total $\mathrm{CaO}$ (grm.) & . & $14 \cdot 286$ & $2 \cdot 121$ & $9 \cdot 047$ & $5 \cdot 771$ & $10 \cdot 693$ & $4 \cdot 600$ & $9 \cdot 753$ & $4 \cdot 272$ \\
\hline Total $\mathrm{P}_{2} \mathrm{O}_{5}$ (grm.) & . & $13 \cdot 823$ & $1 \cdot 606$ & $8 \cdot 293$ & $2 \cdot 137$ & $10 \cdot 613$ & $1 \cdot 807$ & $10 \cdot 721$ & $3 \cdot 126$ \\
\hline$\% \mathrm{CaO}$ & . & $21 \cdot 6$ & $6 \cdot 6$ & $7 \cdot 2$ & $8 \cdot 06$ & $13 \cdot 3$ & $5 \cdot 6$ & $14 \cdot 1$ & $8 \cdot 9$ \\
\hline$\% \mathrm{P}_{2} \mathrm{O}_{5}$ & . & $20 \cdot 9$ & $5 \cdot 0$ & $6 \cdot 6$ & $3 \cdot 0$ & $13 \cdot 2$ & $2 \cdot 2$ & $15 \cdot 5$ & $6 \cdot 7$ \\
\hline Total fat (grm.) ... & . & $17 \cdot 217$ & $14 \cdot 139$ & & & $34 \cdot 588$ & $35 \cdot 357$ & $15 \cdot 978$ & $18 \cdot 408$ \\
\hline Neutral fat (grm.) & . & $2 \cdot 097$ & $2 \cdot 406$ & & & $5 \cdot 974$ & $4 \cdot 116$ & $3 \cdot 711$ & $2 \cdot 592$ \\
\hline Free fatty ac. 'grm.) & . & $7 \cdot 857$ & $4 \cdot 510$ & & & $19 \cdot 754$ & $9 \cdot 324$ & $5 \cdot 883$ & $9 \cdot 72$ \\
\hline Comb. fatty ac. (grm.) & )$\ldots$ & $7 \cdot 263$ & $7 \cdot 223$ & & & $8 \cdot 860$ & $21 \cdot 918$ & $6 \cdot 384$ & $6 \cdot 096$ \\
\hline$\%$ total fat $\quad \ldots$ & . & $26 \cdot 03$ & $44 \cdot 01$ & & & $43 \cdot 02$ & $43 \cdot 04$ & $23 \cdot 10$ & $38 \cdot 35$ \\
\hline$\%$ neutral fat $\ldots$ & .. & $3 \cdot 17$ & $7 \cdot 49$ & & & $7 \cdot 43$ & $5 \cdot 01$ & $5 \cdot 365$ & $5 \cdot 4$ \\
\hline$\%$ free fatty ac. & . & $11 \cdot 88$ & $14 \cdot 04$ & & & $24 \cdot 57$ & $11 \cdot 35$ & $8 \cdot 505$ & $20 \cdot 25$ \\
\hline$\%$ comb. fatty ac. & $\ldots$ & $10 \cdot 98$ & $22 \cdot 48$ & & & $11 \cdot 02$ & $26 \cdot 68$ & $9 \cdot 23$ & $12 \cdot 70$ \\
\hline
\end{tabular}


$\mathrm{P}_{2} \mathrm{O}_{5}$, causing in Case 4 a slightly negative balance of $\mathrm{CaO}$ and a very low positive retention of $\mathrm{P}_{2} \mathrm{O}_{5}$, and in Case $\tilde{5}$, a low positive balance of $\mathrm{CaO}$ and $\mathrm{P}_{2} \mathrm{O}_{5}$. During treatment with irradiation the retentions of $\mathrm{CaO}$ and $\mathrm{P}_{2} \mathrm{O}_{5}$ in both cases were markedly increased owing to a great diminution in the fæcal output of these substances. Unlike the younger children no increase occurred in the excretion of $\mathrm{P}_{2} \mathrm{O}_{5}$ by the kidneys during healing, the amount excreted during both periods being within normal limits.

The results of the analysis of the fæces with regard to the percentage composition and the total content of $\mathrm{CaO}, \mathrm{P}_{2} \mathrm{O}_{5}$ and fat are shown in Tables 4 and 5. It will be seen that not only is there a marked reduction in the

TABLE 5.

Axalyses of Feces before and DURing treathest of late rickets.

\begin{tabular}{|c|c|c|c|c|c|c|c|c|}
\hline & & & & & \multicolumn{2}{|c|}{$\begin{array}{c}\text { Case } 4 . \\
\text { (Irradiation) }\end{array}$} & \multicolumn{2}{|c|}{$\begin{array}{c}\text { Case } 5 . \\
\text { (Irradiation) }\end{array}$} \\
\hline & & & & & 1st Per. & 2nd Per. & lst Per. & 2nd Per. \\
\hline \multirow{2}{*}{\multicolumn{2}{|c|}{$\begin{array}{l}\text { Fæcal weight (grm.).. } \\
\% \text { Ash } \\
\%\end{array}$}} & . & . & . & $110 \cdot 15$ & $32 \cdot 20$ & $76 \cdot 76$ & $42 \cdot 06$ \\
\hline & & . & . & $\cdots$ & $31 \cdot 8$ & $21 \cdot 4$ & $44 \cdot 54$ & $27 \cdot 2$ \\
\hline \multirow{2}{*}{$\begin{array}{l}\text { Total } \mathrm{CaO} \text { (grm.) } \\
\text { Total } \mathrm{P}_{2} \mathrm{O}_{5} \text { (grm.) }\end{array}$} & .. & . & . & . & $17 \cdot 293$ & $2 \cdot 673$ & $14 \cdot 431$ & $4 \cdot 753$ \\
\hline & . & . & . & $\cdots$ & $12 \cdot 006$ & $1 \cdot 803$ & $13 \cdot 970$ & $4 \cdot 332$ \\
\hline \multirow{2}{*}{$\begin{array}{ll}\% & \mathrm{CaO} \\
\% & \mathrm{P}_{2} \mathrm{O}_{5}\end{array}$} & . & . & . & . & $15 \cdot 7$ & $8 \cdot 3$ & $18 \cdot 8$ & $11 \cdot 3$ \\
\hline & . & . & . & . & $10 \cdot 9$ & $5 \cdot 6$ & $18 \cdot 2$ & $10 \cdot 2$ \\
\hline \multirow{4}{*}{\multicolumn{2}{|c|}{$\begin{array}{l}\text { Total fat (grm.) } \\
\text { Neutral fat (grm.) . } \\
\text { Free fatty acid (grm.) } \\
\text { Comb. fatty acid (grm.) }\end{array}$}} & . & . & . & $18 \cdot 758$ & $10 \cdot 052$ & $18 \cdot 775$ & $11 \cdot 971$ \\
\hline & & . & . & . & $3 \cdot 205$ & $2 \cdot 088$ & $2 \cdot 583$ & $2 \cdot 402$ \\
\hline & & . & . & . & $4 \cdot 164$ & $2 \cdot 043$ & $6 \cdot 321$ & $1 \cdot 817$ \\
\hline & & $\cdots$ & $\cdots$ & . & $11 \cdot 389$ & $5 \cdot 921$ & $9 \cdot 871$ & $7 \cdot 752$ \\
\hline \multirow{4}{*}{$\begin{array}{l}\% \text { total fat .. } \\
\% \text { neutral fat } \\
\% \text { free fatty ac. } \\
\% \text { comb. fatty ac. }\end{array}$} & . & . & . & . & $17 \cdot 03$ & $31 \cdot 22$ & $24 \cdot 46$ & $28 \cdot 46$ \\
\hline & . & . & . & $\ldots$ & $2 \cdot 91$ & $6 \cdot 485$ & $3 \cdot 365$ & $5 \cdot 71$ \\
\hline & . & . & . & . & $3 \cdot 78$ & $6 \cdot 345$ & $8 \cdot 235$ & $4 \cdot 32$ \\
\hline & . & . & $\ldots$ & . & $10 \cdot 34$ & $18 \cdot 39$ & $12 \cdot 86$ & $18 \cdot 43$ \\
\hline
\end{tabular}

fæcal weight during healing, but that also a marked decrease occurs in the percentage of ash and in the percentage of $\mathrm{CaO}$ and $\mathrm{P}_{2} \mathrm{O}_{5}$. This is accompanied by an increase in the percentage of total fat and also in the percentage of combined fatty acids. The increase in the percentage of combined fatty acids associated with the relatively greater decrease in percentage of $\mathrm{P}_{2} \mathrm{O}_{5}$ than percentage of $\mathrm{CaO}$ is further evidence of the now well known fact that during the healing phase of rickets there is more fæcal lime in the form of soaps and less in the form of calcium phosphate.

\section{Discussion.}

In assessing the value of the different methods of treatment practical considerations make it necessary to take into account other features than the small differences in the rapidity of healing. Although direct irradiation pro. 
duces immediate and rapid healing, it is not from a practical standpoint the method of choice. The disadvantages of this method include the initial cost of the apparatus, the necessity for constant skilled supervision to avoid damage from excessive exposure, and the frequent regular attendance of the patient at the clinic. The simple oral administration of a preparation rich in the anti-rachitic agent would seem at once more convenient for doctor and patient. In choosing between cod-liver oil and preparations. such as radiostol and vigantol the question of cost is important, particularly in view of the large numbers of children requiring treatment in hospital practice and welfare clinics. From this aspect cod-liver oil is undoubtedly the method of selection. An objection which has frequently been raised to the use of cod-liver oil is the difficulty met with in inducing children to take it. Our experience, however, has been that most children do not object to it and in the few who do, a little persistence usually overcomes any initial dislike. A more important objection is the variable content of the anti-rachitic vitamin in different brands of the oil, but the use of a brand of known anti-rachitic value readily overcomes this disadvantage.

\section{Summary.}

Effective healing was brought about by each of the four methods of treatment. In the mineral metabolism of every case there was produced to a marked degree the changes typical of the healing phase of the disease. The highest retentions of $\mathrm{CaO}$ and $\mathrm{P}_{2} \mathrm{O}_{5}$ occurred during treatment with direct irradiation, but equally rapid healing as judged radiologically and from estimations of the serum calcium and phosphorus was produced by the use of cod-liver oil and vigantol. A somewhat slower improvement, as estimated by all standards, occurred during the administration of radiostol.

\section{REFERENCES.}

1. Huntly, W., Ajmere Rajputana Press, 1889. Quoted by Findlay, L., Brit. Med. J., Lond., 1922 , ii, 846.

2. Huldschinsky, K., Deutsche. Med. Wchnschr., Leipzig, 1919, XLV, 712. Zeit.f. Orth. Chir., Stuttgart, 1919-20, XXXIX, 426.

3. Chick, H., et alii, Med. Res. Council, Sp. Rep. Series, Lond., 1923, No. 77, 74.

4. Braine, J. Carter, and Osman, A. A., Guy's Hosp. Rep., Lond., 1925, LXXV, 491.

5. Kramer, B., Casparis, H., \& Howland, J., Amer. J. Dis. Child., Chic., 1922, XXIV, 20.

6. Meyer, L. F., Internat. Clin., Philad., 1921, IV, 176.

7. Orr, W. J., Holt, I. E., Wilkins, L., Boone, F. H., Amer. J. Dis. Child. Chic. 1923, XXVI, 362 .

8. Karelitz, S., Proc. Soc. Exp. Biol. and Med., N.Y., 1928, XXV, 576. Amer. J. Dis. Child., Chic., 1928, XXXVI, 1108.

9. György, P., Strahlentherapie, Berlin, 1928, XXVIII, 359.

10. Vollmer H. Monat. f. Kind. Leipzig 1928, XXXVIII, 70.

11. Aidin, R., Lancet, Lond., 1928, i, 229.

12. Kramer, B., \& Tisdall, F. F., J. Biol. Chem., Baltimore, 1921, XILVIr, 475.

13. Tisdall, F. F., Loc. cit., 1922, L, 329. . 